УДК 378.147:37.011.3-051:53

https://doi.org/10.52058/2786-4952-2022-1(6)-331-338

Семенишена Руслана Володимирівна кандидат педагогічних наук, доцент, асистент кафедри технічного сервісу i загальнотехнічних дисциплін, Заклад вищої освіти "Подільський державний університет", корпус №1 ПДАТУ, вулиця Шевченка, 13, м. Кам'янець-Подільський, 32316, https://orcid.org/ 0000-0002-2969-3635

Шевчук Олександр Володимирович кандидат педагогічних наук, викладач, навчально-реабілітаційний заклад вищої освіти «Кам'янець-Подільський державний інститут», вул. Годованця, 13, м. Кам'янець-Подільський, 32301, https://orcid.org /0000-0002-0557-2994

\title{
ФОРМУВАННІ ФАХОВОЇ КОМПЕТЕНТНОСТІ СТУДЕНТІВ В УМОВАХ ДИСТАНЦЙНОГО НАЧАННЯ ВІРТУАЛЬНИМ ЛАБОРАТОРНИМ ПРАКТИКУМОМ
}

Анотація. У статті розглядається вплив віртуальних лабораторних робіт на формування фахової компетентності майбутніх фахівців. Організація та проведення лабораторних робіт. Дослідження полягає у виявленні позитивного впливу віртуальної лабораторії на формування професіоналізму майбутніх фахівців, шляхом виконання завдань лабораторного практикуму. На сьогоднішній день велику роль у навчальному процесі відіграє практика можливість відтворити побачене, перевірити певну закономірність, у цьому нам допомагають лабораторні роботи. Адже лабораторні роботи допомагають скоординувати свої знання. Відповідно до національної рамки кваліфікації компетентність це здатність особи до виконання певного виду діяльності, що виражається через знання, розуміння, уміння, цінності, інші особисті якості. Лабораторне заняття - це практичне заняття, цілю якого є реалізація умінь, навичок, переконань 3 використанням приладів, інструментів i iнших технічних засобів. При виконанні лабораторних роботах у студентів формуються експериментаторські здібності, а при роботі в віртуальній лабораторії вони можуть моделювати певні фізичні процеси використвуючи віртуальне обладнання, адже ціни на деякі фізичні лабораторії досить великі. Робота у віртуальних лабораторіях дає можливість проводити велику кількість досліджень. Описано використання віртуальних лабораторій які у процесі вивчення фізики дозволяють проводити експерименти на імітаційних моделях, які є досить наочними, інформативними та допускають зміну параметрів, що може підвищити інтерес до вивчення фізики, розвивати мислення за допомогою нових інформаційних засобів. Крім того, представлені 
інформаційні продукти можна використовувати для проведення самостійними дослідженнями в рамках проектної діяльності з фізики, що $є$ актуальним завданням сучасної освіти.

Ключові слова: професійна компетентність, лабораторний практикум, віртуальна лабораторія.

Semenyshena Ruslana Volodymyrivna Candidate of pedagogical sciences, Associate Professor, Higher Educational Institution «Podillia State University», building №1 PDATU, 13 Shevchenka St., Kamianets-Podilskyi, 32316, https://orcid.org/0000-0002-2969-3635

Shevchuk Oleksander Volodymyrovych Candidate of Pedagogical Sciences, Lecturer, Educational and Rehabilitation Institution of Higher Education "Kamianets-Podilskyi State Institute", Godovantsya St., 13, Kamyanets-Podilsky, 32301, https://orcid.org/0000-0002-0557-2994

\title{
FORMATION OF PROFESSIONAL COMPETENCE OF STUDENTS IN CONDITIONS OF REMOTE STARTING BY VIRTUAL LABORATORY WORKSHOP
}

\begin{abstract}
. the article considers the influence of virtual laboratory works on the formation of professional competence of future specialists, organization and carrying out of laboratory works. The study is to identify the positive impact of the virtual laboratory on the formation of professionalism of future professionals by performing the tasks of the laboratory workshop. For today, an important role in the educational process is played by practice - the ability to reproduce what is seen, to check a certain pattern, in this we are helped by laboratory work. After all, laboratory works help to coordinate their knowledge. According to the national qualification's framework, competence is a person's ability to perform a certain type of activity, which is expressed through knowledge, understanding, skills, values, and other personal qualities. Laboratory lesson is a practical lesson, the purpose of which is the realization of skills, abilities, beliefs with the use of instruments, tools and other technical means. When performing laboratory work, students develop experimental abilities, and when working in a virtual laboratory, they can simulate certain physical processes using virtual equipment, because the prices for some physical laboratories are quite high. And work in virtual laboratories makes it possible to conduct a large number of studies. The use of virtual laboratories is described, which in the process of studying physics allow to conduct experiments on simulation models, which are quite clear, informative and allow changing parameters, which can increase interest in studying physics, develop thinking with new information tools. In addition, the presented information products can be used for independent research in the framework of project activities in physics, which is an urgent task of modern education.
\end{abstract}


Keywords: professional competence, laboratory workshop, virtual laboratory.

Постановка проблеми. Умови сьогоднішніх навчальних буднів перенесені з стін закладів вищої освіти у домашні умови і це все повязане 3 світовою пандемією covid-19 і саме тому розвиток і впровадження віртуальних лабораторних практикумів $є$ не аби як актуальним.

Аналіз останніх досліджень та публікацій. Ряд вітчизняних науковців займаються проблемою вдосконалення навчального процесу в умовах дистанційного навчання, коли студент немає прямого контакту з обладнанням і може взаємодіяти з одногрупниками та викладачем у дистанційному форматі.

Мета статті. Дослідити роль віртуальних лабораторних робіт на формування фахової компетентності студентів в умовах дистанційного навчання.

Виклад основного матеріалу. Освіта сьогодення в умовах пандемії зазнала кардинальних змін зумовлених євроінтеграційним процесом диктує нові умови що до розвитку майбутнього покоління фахівців, досвідчених, висококваліфікованих, компетентних.

На думку психологів, фахова підготовка повинна опиратися на компоненти знання, яким в навчальному процесі не приділяється достатньої уваги - це навички і уміння самостійної роботи, розвиток діалектичного мислення, системний підхід до постановки і розв'язання задач фахової діяльності, вибір провідного виду діяльності, розвиток творчої уяви, виховання ініціативи, уміння приймати рішення тощо. Такі особистісні якості легко формуються на суб'єкт-об'єктній основі організації навчального процесу. Подібна постановка проблеми вимагає якісно нового підходу щодо формування фахових знань майбутніх фахівців економіки. На сучасному етапі реформування освіти особливої уваги заслуговують здобутки фундаментального характеру провідних науковців щодо прогнозування, об'єктивізації, діагностики та управління фаховою підготовкою.

Проблемою розвитку фахової компетентності займається багато дослідників які зробили великий внесок у скарбницю розвитку фахової компетентності. Актуальними питаннями методики навчання лабораторних робіт визначаються напрямки активізації та мотивації навчально-пізнавальної діяльності [5]. Проблеми організації пізнавального процесу 3 легко розв'язуються за умов збільшення об'єму дидактичного матеріалу 3 використання еталонних вимірників якості фізичних знань, удосконалення системи викладу навчального матеріалу 3 використанням дидактичних ресурсів, чим і займаються ряд вчених-дослідників [3; 7]: П.С.Атаманчук, B.I. Баштовий, С.П.Величко, О.І.Ляшенко, І.В. Корсун, С.В.Коршак, В.В.Мендерецький, А.І. Павленко, В.Д. Сиротюк та інші.

Спільним у визначеннях дослідників поняття «компетентність» $\epsilon$ розуміння пї як здатності індивіда справлятися з усілякими задачами, як сукупність знань, які необхідні для виконання конкретної роботи; як певні 
Журнал«Герспективита інноваціїнукиљ

(Серія«Гедагогіка», Серія«Гцихологія», Серія«Медицинв»

№1(6) 2022

стратегії для реалізації творчого потенціалу особистості. Злагоджена взаємодія цієї безлічі окремих аспектів приводить нас до комплексного розуміння компетентності, що виявляється у контексті умов і вимог, як зовнішніх, так i внутрішніх [4]

На сьогоднішній день велику роль у навчальному процесі відіграє практика - можливість відтворити побачене, перевірити певний закон чи закономірність, у цьому нам допоможе лабораторний практикум. Адже лабораторні роботи допоможуть нашим студентам скоординувати свої знання. Відповідно до національної рамки кваліфікації компетентність це здатність особи до виконання певного виду діяльності, що виражається через знання, розуміння, уміння, цінності, інші особисті якості [6]. Розвиток фахової компетентності викладача допоможе розвинути такі аспекти свої професійної діяльності як:

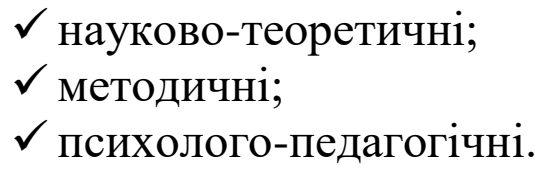

Одним із основних занять для студентів економічного профілю $\epsilon$ лабораторна робота (комплексне дослідження), а самі лабораторні роботи класифікують за такими ознаками: фронтальні лабораторні роботи, фізичні практикуми, домашній експеримент.

Самі лабораторні роботи проводяться за одним із методів, а саме: репродуктивним, частково-пошуковим (евристичним), проблемно-пошуковим або дослідницьким.

Репродуктивний метод виконання лабораторної роботи полягає в тому, що в даному випадку не передбачається самостійне здобуття нових знань, а лише підтверджуються вже відомі факти й істини або ілюструються теоретично встановлені твердження [6]. Такі лабораторні роботи регламентують порядок проведення самої роботи і вимагають від викладача науково-теоретичних та методичних навиків для організації такої роботи.

Дослідницький метод у чистому вигляді може бути використаний лише в індивідуальній роботі з студентами які мають кращу успішність [2].

А лабораторні роботи частково-пошукового характеру та проблемнопошукового вимагають своєрідного психолого-педагогічного підходу, адже ці лабораторні роботи у порівнянні з вище перерахованими у своїй структурі не мають такого елемента як «Хід роботи» і студенти самостійно будують свою роботу, складають план, грунтуючись на назві роботи та меті. При виконанні цих робіт частково-пошукового характеру чи проблемно-пошукового характеру студент на практиці може продемонструвати ті знання, які засвоїв на лекційних курсах та застосує на практиці, адже саме від засвоєних знань залежить результат лабораторного дослідження. Така організація вимагає врахування психолого-педагогічні комунікації. Психолого-педагогічна підготовленість складається із знань методологічних основ i категорій педагогіки; закономірностей соціалізації і розвитку особистості: суті, цілей і 
технологій навчання та виховання; законів вікового анатомо-фізіологічного i психічного розвитку [7].

Лабораторне заняття, як форма навчання для вироблення знань, має велику продуктивність, ніж лекційне чи практичне заняття формування вмінь i навичок. На цьому занятті відсутня регламентація навчальної діяльності, дається великий простір для прояву ініціативи і винахідливості. Завдяки цьому студенти виконують великий обсяг роботи, велику кількість тренувальних дій. Заняття такого характеру ефективніше, ніж лекція, адже воно сприяє формування самостійності як якості особистості:

планування своєї роботи,

- усвідомлено прагнути до мети,

- ефективніше займатись самоконтролем.

Однак варто відмітити, що лабораторні заняття проводяться тільки після лекцій і інших форм організації навчання.

У професійному навчанні лабораторні роботи займають проміжне положення між теоретичним i виробничим навчанням i служать одним 3 найважливіших засобів здійснення теорії і практики. При цьому з одного боку, досягається закріплення й удосконалювання знань студентів, з іншого боку - у них формуються визначені професійні уміння, що потім застосовуються у процесі виробничого навчання.

Лабораторне заняття - це практичне заняття, що проводиться як індивідуально, так і із групою студентів; його ціль - реалізація умінь, навичок, переконань $з$ використанням приладів, інструментів і інших технічних засобів, тобто це вивчення різних явищ за допомогою спеціального устаткування яке обирається самостійно, керуючись здобутими знаннями [5]. Студенти опановують систему засобів і методів дослідження:

експериментального,

практичного,

розширення можливостей використання теоретичних знань для розв'язку практичних задач.

Зараз неможливо уявити навчальний процес без використання сучасних інформаційних технологій, інформаційних та комунікаційних засобів які в свою чергу сприяють зростанню професіоналізму та освітніх можливостей навчального процесу. Фізика - наука експериментальна, тому фізичний експеримент у вигляді демонстраційних дослідів та лабораторних робіт $\epsilon$ невід'ємною частиною навчального процесу. Найчастіше всі лабораторні роботи та експерименти проводяться безпосередньо в аудиторії. На жаль, не завжди є можливість продемонструвати певний фізичний експеримент в умов лабораторії, проте цю проблему можна вирішити за допомогою віртуальних лабораторій. Існує велика кількість програмних продуктів, які дають можливість реалізовувати імітаційні моделі реальних експериментів, що базуються на різних програмно-апаратних платформах. Віртуальні лабораторії дозволяють самостійно займатися експериментальною роботою. 
Журнал«Герспективитаінновації наукиљ

(Серія «Гедагогіка», Серія«ГЕихологія», Серія«Медицина»

№1(6) 2022

Розглянемо деякі програми:

найбільш зручні у використанні віртуальні фізичні лабораторії «Експерименти вдома».

Цей додаток має зручний інтерфейс у ньому представлено чотири групи експериментів: 3 водою, з їжею, з вогнем та досліди без категорії. У кожному блоці міститься від 3 до 7 експериментів.

Кожен досвід містить докладний опис його проведення, що включає перелік необхідних компонентів, які можна придбати у звичайному магазині. Наводиться опис ходу експерименту, в якому описуються всі його кроки 3 детальними та інформативними ілюстраціями. Після опису досвіду слідує його пояснення, де докладно розповідається, за рахунок чого відбувається те чи інше явище і чому.

Додаток Virtual Lab «Mechanics» Demo.

У цьому додатку представлено одинадцять лабораторних робіт, що моделюють механічні явища, які можна використовувати, зокрема, і для поглибленого вивчення деяких розділів кінематики та динаміки. Розглянуто такі теми як: рівноприскорений рух, рух з рівномірним прискоренням, закони зіткнення, вільне падіння, пуск під кутом, обертальний рух з рівномірним прискоренням, момент інерції горизонтального стрижня, визначення моменту різних тіл, маятник Максвелла.

Програма також зручна тим, що дає можливість змінювати масштаб картинки та кут огляду, що дозволяє розглянути досвід під різними кутами. Програма підтримує англійський та російський інтерфейс. Цей застосунок також реалізує тривимірну модель унікального чи типового обладнання. Максимальне наближення до реальних умов роботи дає можливість 3 високим ступенем реальності брати участь у фізичному експерименті.

Додаток «Physic Virtual Lab».

У віртуальній лабораторії «Physic Virtual Lab» $є 6$ різних блоків для проведення фізичних експериментів: Light (природа світла), Mechanic (механіка), Electricity and Magnetism (електрика та магнетизм), Waves (хвильові явища), Thermodynamic (термодинаміка), Quantum (квантова механіка).

Кожен блок включає кілька лабораторних робіт 3 тем розділу. Представлені моделі фізичних дослідів супроводжуються яскравою графікою, що забезпечує привернення уваги до досліджуваного процесу. Однією 3 головних переваг цієї програми $є$ можливість зміни параметрів моделей та супровід майже кожного досвіду фізичною формулою. Ця лабораторія доступна тільки англійською мовою

Використання віртуальних лабораторій у процесі вивчення фізики дозволяє проводити експерименти на імітаційних моделях, які є досить наочними, інформативними та допускають зміну параметрів, що може підвищити інтерес до вивчення фізики, розвивати мислення за допомогою нових інформаційних засобів. Крім того, представлені інформаційні продукти 
можна використовувати для проведення самостійними дослідженнями в рамках проектної діяльності з фізики, що $є$ актуальним завданням сучасної освіти.

Якщо розміщення будь-якого лекційного матеріалу може бути повністю виконане за допомогою спеціалізованої програми ВооквСтеаТог. створення автоматизованої системи, що забезпечує грамотне виконання лабораторної роботи вимагає особливого підходу з урахуванням специфіки поставленого завдання.

Розглянемо одну з лабораторних робіт віртуальної лабораторії з фізики, яка полягає у визначенні коефіцієнта в'язкості рідини методом Стокс. Для цього необхідно докладно ознайомитися 3 реальною установкою, вибрати мову програмування, розробити інтерфейс та створити закінчений додаток для виконання лабораторної роботи

Віртуальна лабораторія повинна обов'язково містити опис лабораторної роботи, реальної установки, віртуальну модель установки та їі опис, необхідні теоретичні відомості на цю тему, таблиці для запису результатів. Лабораторія повинна надати користувачеві можливість зробити лабораторну роботу, не виходячи з дому, але маючи при цьому постійну можливість консультування у викладача. Робота полягає в наступному: користувач опускає кульку в колбу 3 гліцерином, вимірює діаметр кульки за допомогою лінійки, обчислює коефіцієнт в'язкості рідини. Для цього необхідна установка, що складається 3 колби з гліцерином, набір кульок різного діаметру та мікроскоп!

Як правило, усі лабораторні заняття по визначеній навчальній дисципліні поєднуються в єдину систему i звуться «лабораторний практикум», що дозволяє говорити про існування значної подібності між лабораторними i практичними формами проведення занять.

Лабораторні роботи - найбільш цінний метод навчання, адже він вимагає компетентнісного підходу i характеризується організацією пізнавальної діяльність у лабораторії, розвиває світоглядність студентів. Застосування лабораторних робіт виявляється корисним у викладанні багатьох навчальних дисциплін [6].

Висновки. Проблема методичної підтримки процесу навчання постійно є предметом уваги переважної більшості викладачів. Внаслідок їх зусиль сучасна дидактика, в своїх проектно-креативних розбудовах, має можливість визначатись i утверджуватись, опираючись на широкий арсенал засобів навчання, що розробляються для доповнення (або ж і часткової заміни) підручника. Це - робочі зошити, дидактичні матеріали, методичні рекомендації, конкретні методики, методичні керівництва, методичні доповнення, методичні коментарі, збірники, моделі, таблиці, програмні засоби, системи штучного інтелекту для організації процесу самонавчання (навчальні бази даних, експертні навчальні системи, навчальні бази знань), навчальне та демонстраційне обладнання, спряжене 3 комп'ютером, навчальні аудіо - та відеозаписи, система «віртуальної реальності» (технологія мультимедіа), 


\section{Лimepamypa:}

1. Атаманчук П.С. Інноваційні технології управління навчанням фізики: монографія / П.С. Атаманчук. - Кам'янець-Подільський : Кам’янець-Поділ. держ. пед. ун-т, 1999. - 174 с.

2. Атаманчук П.С. Методичні основи управління навчанням фізики : монографія / П.С. Атаманчук, О.М. Семерня. - Кам'янець-Подільський : Кам'янець-Подільський державний університет, інформаційно-видавничий відділ, 2005. - 196 с.

3. Батышев С.Я. Профессиональная педагогика: учебник для студентов, обучающихся по педагогическим специальностям и направлениям. 2-е изд., перераб. и доп. / С.Я. Батышев. - М.: Ассоциация «Профессиональное образование», 1999. - 904 с.

4. Кузьмина Н.В. Профессионализм деятельности преподавателя и мастера производственного обучения / Н.В. Кузьмина. - М.: Высшая школа, 1989. - 167 с.

5. Національна рамка кваліфікації [Електронний ресурс]. - Режим доступу: http://zakon4.rada.gov.ua/laws/ show/1341-2011-\%D0\%BF.

6. Професійна компетентність [Електронний ресурс]. - Режим доступу: http://books.br.com.ua/25647.

7. Шевчук О.В. Формування наукового світогляду студентів в процесі виконання лабораторних робіт / О.В. Шевчук, Р.В. Семенишена // Науковий часопис Національного педагогічного університету імені М.П. Драгоманова : збірник наукових праць / М-во освіти і науки України, Нац. пед. ун-т ім. М.П. Драгоманова. - Київ : Вид-во НПУ ім. М. П. Драгоманова, 2015. - Серія 3 : Фізика і математика у вищій і середній школі. Вип. 15. - С. 106-113.

\section{References:}

1. Atamanchuk, P.S. (1999). Innovacijni tehnologii' upravlinnja navchannjam fizyky [Innovative technologies for managing the teaching of physics]. Kam'janec'-Podil's'kyj : Kam'janec'-Podil. derzh. ped. un-t [in Ukrainian].

2. Atamanchuk, P.S., \& Semernja, O.M. (2005). Metodychni osnovy upravlinnja navchannjam fizyky [Methodical bases of management of teaching of physics]. Kam'janec'-Podil's'kyj : Kam'janec'Podil's'kyj derzhavnyj universytet, informacijno-vydavnychyj viddil [in Ukrainian].

3. Batyshev, S. Ja. (1999). Professional'naja pedagogika [Professional pedagogy]. M.: Associacija «Professional'noe obrazovanie» [in Russian].

4. Kuz'mina, N.V. (1989). Professionalizm dejatel'nosti prepodavatelja i mastera proizvodstvennogo obuchenija [Professionalism of the teacher and master of industrial training]. M.: Vysshaja shkola [in Russian].

5. Nacional'na ramka kvalifikacii' [National qualifications framework]. (n.d.). zakon4.rada.gov.ua. Retrieved from http://zakon4.rada.gov.ua/laws/show/1341-2011-\%D0\%BF/ [in Ukrainian].

6. Profesijna kompetentnist' [Professional competence]. (n.d.). books.br.com.ua Retrieved from http://books.br.com.ua/25647/ [in Ukrainian].

7. Shevchuk, O.V. \& Semenyshena, R.V. (2015). Formuvannja naukovogo svitogljadu studentiv v procesi vykonannja laboratornyh robit [Formation of students' scientific worldview in the process of laboratory work] Naukovyj chasopys Nacional'nogo pedagogichnogo universytetu imeni M.P. Dragomanova : zbirnyk naukovyh prac'. M-vo osvity i nauky Ukrai'ny, Nac. ped. un-t im. M.P. Dragomanova. - Kyi'v : Vyd-vo NPU im. M. P. Dragomanova, - Serija 3 : Fizyka i matematyka u vyshhij i serednij shkoli. - Vyp. 15. 